\section{Morphology, Physiology, Survival, and Field Performance of Containerized Coastal Douglas Fir Seedlings Given Different Dormancy-induction Regimes}

\author{
Joanne E. MacDonald ${ }^{1}$ \\ Natural Resources Canada, Canadian Forest Service-Atlantic Forestry \\ Centre, P.O. Box 4000, Fredericton, NB, E3B 5P7, Canada
}

\author{
John N. Owens \\ Department of Biology, Centre for Forest Biology, University of Victoria, \\ P.O. Box 3020 STN CSC, Victoria, BC, V8W 3N5, Canada
}

Additional index words. Pseudotsuga menziesii var. menziesii, bud endodormancy, dry weight, days to budbreak, root growth capacity

\begin{abstract}
The effects of different dormancy-induction regimes on first-year containerized coastal Douglas fir [Pseudotsuga menziesii (Mirb.) Franco var. menziesii] seedling morphology and physiology in the nursery, as well as seedling survival and performance after one growing season in a common garden, were investigated. In early July, three dormancy-induction regimes were applied: moderate moisture stress (MS), short day (SD), and short day with moderate moisture stress (SD+MS). In early October, seedling height, root collar diameter, and shoot dry weight were unaffected by regime, but root dry weight was reduced in seedlings from the MS and SD+MS regimes compared with the SD regime. At this time, morphogenesis was completed in all terminal buds of seedlings from both SD regimes, whereas it continued in all terminal buds of seedlings from the MS regime. Furthermore, $25 \%$ to $88 \%$ of terminal buds from the SD regimes were endodormant, but none from the MS regime were endodormant. In March, budbreak occurred at the same time in seedlings from the two SD regimes and was earlier than in seedlings from the MS regime; root growth capacity was unaffected by regime. After one growing season, there were no regime differences in seedling survival, root collar diameter, shoot dry weight, root dry weight, length of the current-year leader, or number of needles on the leader.
\end{abstract}

Coastal Douglas fir [Pseudotsuga menziesii (Mirb.) Franco var. menziesii] is one of the most important and valuable timber species in temperate forestry (Hermann and Lavender, 1990). Between 2000 and 2005, 38.1 million containerized coastal Douglas fir seedlings were planted on Crown lands in British Columbia [J. McClarnon, British Columbia Ministry of Forests (BCMOF),

\footnotetext{
Received for publication 17 May 2006. Accepted for publication 26 June 2006. This study was funded in part by a Natural Sciences and Engineering Research Council of Canada discovery grant (A1982) to J.N.O. We thank Sandy Maher and staff of the Angus P. MacBean Nursery for their cooperation; Brad Binges, Rhonda Korol, Don Skinner, and Paul Woodcock for technical assistance; Kathy Beaton for digital micrograph construction; and Dr. Jan Bonga, Rob Scagel, and anonymous reviewers for thoughtfully reviewing the manuscript. Trade names are necessary to report factually; however, the use of a name implies no endorsement by Natural Resources Canada of the product to the exclusion of others that may also be suitable.

${ }^{1}$ To whom reprint requests should be addressed; e-mail jomacdon@nrcan.gc.ca.
}

personal communication, 2006]. Production of containerized coastal Douglas fir is increasing in the Pacific Northwest region of the United States despite that region's long tradition of bareroot nurseries. For example, one container nursery in Oregon shipped 6.5 million coastal Douglas fir seedlings over the course of 2004 and 2005 (K. Giles, PRT Oregon, personal communication, 2006). Currently, nurseries in both countries use moderate moisture stress (MS), short days (SD), or short days with moderate moisture stress ( $\mathrm{SD}+\mathrm{MS})$ as a dormancy-induction regime for coastal Douglas fir (R. Merrell, BCMOF, and K. Giles, PRT, personal communication, 2006).

Earlier studies of western hemlock [Tsuga heterophylla (Raf.) Sarg.] (Grossnickle et al., 1991a, 1991b; O'Reilly et al., 1989a, 1989b, 1994a, 1994b) and western red cedar (Thuja plicata Donn ex D. Don) (Krasowski and reported the effects of these regimes on seedling morphology and physiology in the nursery and outplanting performance. Unfortunately, these results cannot be applied to coastal Douglas fir because the three species vary in architecture and shoot growth Owens, 1991; Krasowski et al., 1990) have pattern and, thus, they respond differently to nursery culture. Western hemlock is characterized by abundant current-year branching along its leader, and although a terminal bud does form, only part of next year's leader growth is preformed in the nursery; the remainder is neoformed on the planting site (O'Reilly et al., 1994b). [In the preformed component of the leader, leaves and their subtending internodes are initiated and undergo dormancy before elongating, whereas in the neoformed portion of the leader, they are initiated and elongate immediately (Hallé et al., 1978).] Western red cedar also has abundant current-year branching along its leader, but the species does not form terminal buds. However, the shoot apical meristem is protected by the last formed scale-like leaves and thus, leader growth after planting is fully neoformed (Krasowski and Owens, 1991). In contrast, coastal Douglas fir has one strongly defined leader with little current-year branching on the leader and then only in proximal positions. Leader growth for the following year is preformed during nursery culture, but there may be late summer lammas growth on the planting site (Carlson and Preisig, 1981).

The objectives of this research were to examine the effects of MS, SD, and SD+MS dormancy-induction regimes on coastal Douglas fir seedling morphology and physiology in the nursery as well as seedling survival and performance after one growing season in a common garden. In the nursery component, a stock quality assessment approach was used, which measures both material (i.e., morphology and physiology) and performance (i.e., response to test conditions) attributes at select points in time (Grossnickle et al., 1991a; Grossnickle and Folk, 2005; Ritchie, 1984).

\section{Materials and Methods}

\section{Nursery culture}

Seedlings from one coastal Douglas fir seedlot (BCMOF Registered Seedlot No. $4505,48^{\circ} 49^{\prime} \mathrm{N}, 123^{\circ} 56^{\prime} \mathrm{W}$, elevation 610 $\mathrm{m})$, which were part of the commercial crop grown at the Angus P. MacBean Nursery in Yellow Point, B.C., Canada $\left(49^{\circ} 4^{\prime}\right.$ N, $\left.123^{\circ} 55^{\prime} \mathrm{W}\right)$, were used. Stratified seeds were sown in early April in British Columbia/ Canadian Forest Service Plug Styrofoam Block (BC/CFS PSB) Styroblock 313A containers (198 cavities per container or 936 cavities $\cdot \mathrm{m}^{-2}, 60-\mathrm{mL}$ volume per cavity, 13.3$\mathrm{cm}$ cavity depth, 2.8-cm cavity top diameter) (Beaver Plastics Ltd., Edmonton, Alberta, Canada). The substrate mix was 2 peat: 1 vermiculite (by volume) with a planned bulk density of $0.09 \mathrm{~g} \cdot \mathrm{mL}^{-1}$. Nutricote Type 360 slow-release fertilizer $(16 \mathrm{~N}-4.4 \mathrm{P}-8.3 \mathrm{~K}$; Chisso-Asahi Fertilizer Co., Ltd., Tokyo, Japan) was incorporated into the mix at a rate of $1.3 \mathrm{~kg} \cdot \mathrm{m}^{-3}$. A mobile overhead boom system delivered misting and irrigation. Containers were misted during germination. Thereafter, during each irrigation, water was delivered until the substrate was saturated and gravitational water was draining 
from cavity bottoms. At container capacity (Handrek and Black, 1989), containers were weighed. Irrigation occurred when container mass, randomly sampled throughout the greenhouse, was $2 \mathrm{~kg}$ below the mass at container capacity.

Fertilizer was applied during each irrigation. A forestry seedling starter fertilizer $(11 \mathrm{~N}-17.9 \mathrm{P}-6.6 \mathrm{~K})$ with micronutrients was applied at a rate of $500-750 \mathrm{mg} \cdot \mathrm{L}^{-1}$ during April and May. Subsequently, a high nitrate forestry seedling fertilizer $(20 \mathrm{~N}-3.4 \mathrm{P}-$ $16.6 \mathrm{~K})$ with micronutrients was applied at a rate of $750 \mathrm{mg} \cdot \mathrm{L}^{-1}$ during June and July. From August on, a forestry seedling finisher fertilizer $(8 \mathrm{~N}-8.7 \mathrm{P}-24.9 \mathrm{~K})$ with micronutrients was applied at a rate of $750 \mathrm{mg} \cdot \mathrm{L}^{-1}$. Iron chelate $(13 \% \mathrm{Fe})$ and a soluble trace element $\operatorname{mix}(13 \% \mathrm{~S}, 1.35 \% \mathrm{~B}, 2.3 \% \mathrm{Cu}$, $7.5 \% \mathrm{Fe}, 8 \% \mathrm{Mn}, 0.04 \% \mathrm{Mo}$, and $4.5 \% \mathrm{Zn}$ ) were applied, as needed, to adjust the foliar nutrition levels. Calcium nitrate $(15.5 \% \mathrm{~N}$, $20 \% \mathrm{Ca}$ ) was applied, as needed, to maintain the $\mathrm{pH}$ of the growing substrate between 4.5 and 5.5 .

\section{Dormancy-induction regimes}

Two adjacent greenhouses identical in structure and orientation were used for the dormancy-induction regimes. For the MS regime, the polyethylene roof and sidewalls of the greenhouse were removed before the regime began. However, in the greenhouse used for the two SD regimes, the roof and sidewalls remained intact, protecting the computer-automated, blackout curtain system (with silver-colored exterior surface) that controlled photoperiod (VRE Greenhouse Systems, Stoney Creek, Ontario, Canada). To control temperature and humidity below the curtain system, four $1.5-\mathrm{m}$ diameter exhaust fans (which were externally hooded with blackout curtain material to prevent light leaks) in the end walls vented when greenhouse temperatures reached $25{ }^{\circ} \mathrm{C}$. Greenhouse space above the curtain system was vented by a jet tube suspended below the ridge.

By the end of June, crop height averaged $16 \mathrm{~cm}$ and was within reach of the target specification (BCMOF, 2003). The three dormancy-induction regimes began in early July. The duration of the MS regime was 2 weeks and that of the SD regime was 4 weeks. The SD+MS regime was a combination, i.e., a 4-week SD regime with an initial 2-week MS regime.

The MS regime, developed by the BCMOF (Matthews, 1982) is the industry standard in British Columbia (R. Merrell, BCMOF, personal communication, 2006). Before the regime began, fertilizer application ended and the substrate was leached of mineral salts. Once the regime began, container weight was monitored until it was $3 \mathrm{~kg}$ below the mass at container capacity. At this container weight, predawn equilibrium water potentials of seedling shoots, determined by a pressure chamber technique (Ritchie and Hinckley, 1975), ranged from -1.0 to -1.5 $\mathrm{MPa}$. Then, as soon as seedling shoot tips wilted, containers were watered until the substrate was saturated and gravitational water was draining. During the 2 weeks of the MS regime, seedling shoot tips reached the wilting stage twice. After the regime ended, irrigation with the high-nitrate forestry seedling fertilizer $(20 \mathrm{~N}-3.4 \mathrm{P}-16.6 \mathrm{~K})$ with micronutrients, applied at a rate of $750 \mathrm{mg} \cdot \mathrm{L}^{-1}$, resumed when container weight was $2 \mathrm{~kg}$ below the mass at container capacity.

For both SD regimes, the photoperiod was 8 hours, from 8:00 AM to 4:00 PM. During the SD regime, irrigation with fertilizer continued to occur when container weight was $2 \mathrm{~kg}$ below the mass at container capacity. However, in the SD+MS regime, the first 2 weeks in SD were concurrent with a 2-week MS regime, which was identical to that described here. Seedling shoot tips wilted twice during this 2 -week period. The $\mathrm{SD}+\mathrm{MS}$ regime was separated from the remaining crop by a buffer, two containers wide, to prevent irrigation water from reaching the containers.

In early August, after the two SD regimes ended, containers were moved to the MS greenhouse (under ambient photoperiod and temperature). Containers from the three regimes were placed next to each other to ensure the same postinduction conditions. In addition, containers from the SD regimes were placed so as to maintain their original location within the greenhouse. In late October, the polyethylene glazing was installed on the greenhouse. From mid-November until late March, greenhouse temperature was maintained at $5{ }^{\circ} \mathrm{C}$.

\section{Experimental design}

A modified split-plot experimental design was used in the nursery. There were two main plots in the greenhouse used for the SD and $\mathrm{SD}+\mathrm{MS}$ regimes and one main plot in the greenhouse used for the MS regime. Each main plot consisted of four blocks, each corresponding to a metal pallet. Each pallet held 30 containers; the inner group of 12 containers comprised the experimental units and was surrounded by a buffer one container wide. Containers from which seedlings were sampled for the three assessments were
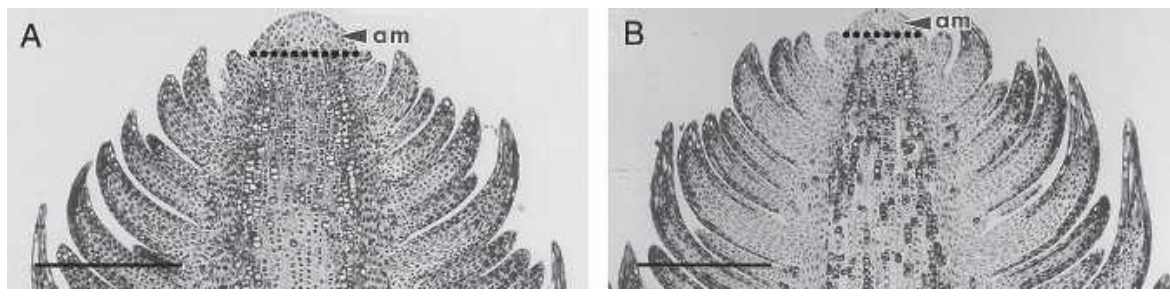

Fig. 1. Light micrographs of median longitudinal sections through the distal portion of the terminal bud in early October of coastal Douglas fir seedlings given different dormancy-induction regimes in July. The shoot apical meristem (am) is the dome of tissue above the dotted line drawn between the last-initiated primordia. Scale bar $=500 \mu \mathrm{m}$. (A) Initiation of needle primordia by the shoot apical meristem is ongoing in a seedling from the moderate moisture stress (MS) regime. The shoot apical meristem is larger than in $\mathbf{B}$ and there is space for more needle primordia to form on each flank of the meristem. (B) Morphogenesis of the terminal bud is completed in a seedling from the short day (SD) regime that is also representative of a seedling from the short day with moderate moisture stress (SD+MS) regime. The shoot apical meristem is at its annual minimum size. 
Molder, 1973) (see Fig. 1A, B). The onset of bud endodormancy was delineated by an absence of mitoses in the shoot apical meristem (Owens and Molder, 1973; see also Arora et al., 2003; Burr, 1990; Carlson et al., 1980; Krasowski and Owens, 1994; Lavender, 1991). Endodormancy is the suspension of growth in any plant structure containing a meristem that is regulated by physiological factors inside the structure (ASHS, 2002). The presence of each cell in mitoses within the meristem (defined as the dome above the most recently initiated needle primordia) and its location relative to the morphogenic zone of the meristem were recorded.

\section{Assessment in March}

After overwintering in the greenhouse, 20 seedlings per regime (five from each block) were sampled in mid-March for the days to budbreak and root growth capacity tests. Four seedlings were dibbled into each pot $(3 \mathrm{~L})$; pots were loosely filled with a 2 peat: 2 vermiculite:1 sand (by volume) substrate mix. Pots were watered until the substrate was saturated and gravitational water was draining, and placed in a controlled-environment chamber (Conviron E15; Controlled Environment Ltd., Winnipeg, Manitoba, Canada) illuminated with a mixture of incandescent and cool-white fluorescent lamps giving an irradiance of $500 \mu \mathrm{mole} \cdot \mathrm{m}^{-2} \cdot \mathrm{s}^{-1}$. Growing conditions were $20: 20{ }^{\circ} \mathrm{C}$ day:night temperature and a 16-hour photoperiod. The substrate was maintained at saturation. Every 3 days, the terminal buds were examined and budbreak was recorded when the emerging shoot became visible just above the budscales. After 15 days, roots were washed clean of substrate and root growth capacity (Ritchie, 1984) was measured by counting the number of white roots $\geq 0.5 \mathrm{~cm}$.

\section{Assessment after one growing season}

In late March, 24 seedlings per regime (six from each block) were sampled and identified using nursery tags. Seedlings were planted at $0.25-\mathrm{m}$ spacing in a common garden, which had been recently ploughed and rotovated, in an abandoned farm field. In late October, seedling survival was recorded and then seedlings were excavated. If the seedling was alive, the root system was washed clean of soil. Then, root collar diameter and length of the current-year leader were measured, the root was clipped from the shoot, each component was bagged separately, and dry weights were determined as described here. Then, the number of needles on the current-year leader that were initiated during terminal bud morphogenesis in the nursery were counted.

\section{Statistical analysis}

All data examination and analyses were conducted using SYSTAT 11 (SYSTAT Software, Inc., 2004). Data were not transformed because they had normal distribution and homogeneity of variances. Because of the operational constraint that crops had to be given a dormancy-induction regime, the set of regimes we investigated is classified as an incomplete block design, and thus, a general linear model analysis of variance (ANOVA) (SYSTAT Software, Inc., 2004) was used to analyze seedling height, leader length, needle number, root collar diameter, shoot and root dry weight, days to budbreak, and root growth capacity data. The model of the ANOVA follows:

$$
\mathrm{Y}_{i j}=\mu+\mathrm{R}_{i}+\mathrm{B}_{j}+\mathrm{RB}_{i j}+\varepsilon_{k(i j)}
$$

where $\mu$ is the mean; $Y_{i j}$ is the measured variable for the $(i, j)^{\text {th }}$ cell; $\mathrm{R}_{i}$ is the fixed effect of dormancy-induction regime, $i=1,2$, 3 ; $\mathrm{B}_{\mathrm{j}}$ is the random effect of blocking in the greenhouse, $k=1,2,3,4$; in the controlledenvironment chamber, $k=1,2,3,4,5$; or in the common garden, $k=1,2$; $\mathrm{RB}_{i j}$ is the effect of the interaction between $\mathrm{R}$ and $\mathrm{B}$; $k$ is the seedling; and $\varepsilon_{k(i j)}$ is the experimental error. A sequential sums of squares was used to test hypotheses. Finally, where there were significant differences in main effects, an orthogonal contrast analysis was run. Percentage data for completion of terminal bud morphogenesis, onset of terminal bud endodormancy, and survival after one season were analyzed with Pearson $\chi^{2}$ goodness of fit using a one-way loglinear model.

\section{Results and Discussion}

Although all dormancy-induction regimes for coastal Douglas fir seedlings began in early July, the response of morphological and physiological attributes in early October was variable. Regime effects on seedling height, root collar diameter, and shoot dry weight were not significantly different (Table 1 ). In contrast, regime effects on root dry weight, completion of terminal bud morphogenesis, and onset of terminal bud endodormancy were significant (Table 1). Root dry weight was significantly reduced in seedlings from the MS and SD+MS regimes compared with the SD regime (Tables1 and 2). We speculate that this reduction was incited by fewer roots because of mortality in response to MS (van Eerden and Gates, 1990). Morphogenesis was completed in all buds from the two SD regimes, whereas it was still ongoing in all buds from the MS regime (Table 1, Fig. 1). Most buds from the SD regime were endodormant (defined by an absence of mitoses in the shoot apical meristem), only some buds from the $\mathrm{SD}+\mathrm{MS}$ regime were endodormant, but no buds from the MS regime were endodormant (Table 1). Furthermore, in the buds from the three regimes that were not yet endodormant, the location of mitoses relative to the morphogenic zone within the shoot apical meristem varied by regime and was important because completion of morphogenic activity is a prerequisite for bud endodormancy (Arora et al., 2003; Owens and Molder, 1973). In seedlings from both SD regimes, mitoses were not in areas of the meristem involved in morphogenesis. In contrast, mitoses continued in the morphogenic zone within the meristem of seedlings from the MS regime.

The dormancy-induction regime had a significant effect on days to budbreak in midMarch (Table 3). Budbreak occurred at the same time in seedlings from the two SD regimes and was significantly earlier than in seedlings from the MS regime (Tables 3 and 4). In contrast, root growth capacity of seedlings from the three regimes was not significantly different (Table 3). Moreover, these values indicate that the seedlings had good physiological integrity (Grossnickle, 2000). Also, the root growth capacity values predicted high survival rates after planting because the test was conducted close to the planting date (Simpson and Ritchie, 1997).

Table 1. Material attributes of containerized coastal Douglas fir seedlings given different dormancy-induction regimes. ${ }^{\mathrm{z}}$

\begin{tabular}{|c|c|c|c|c|}
\hline \multirow[b]{2}{*}{ Attribute } & \multicolumn{3}{|c|}{ Dormancy-induction regime ${ }^{y}$} & \multirow[b]{2}{*}{$P$} \\
\hline & MS & SD & $\mathrm{SD}+\mathrm{MS}$ & \\
\hline Seedling ht (cm) & $22.4 \pm 0.4$ & $23.6 \pm 0.5$ & $21.7 \pm 0.5$ & 0.3700 \\
\hline Root collar diam (mm) & $3.2 \pm 0.1$ & $3.5 \pm 0.1$ & $3.3 \pm 0.1$ & 0.4980 \\
\hline Shoot dry wt (g) & $1.37 \pm 0.08$ & $1.45 \pm 0.07$ & $1.25 \pm 0.07$ & 0.5251 \\
\hline Root dry wt (g) & $0.62 \pm 0.03$ & $0.73 \pm 0.03$ & $0.59 \pm 0.04$ & 0.0754 \\
\hline \multicolumn{5}{|l|}{ Percentage of terminal buds that } \\
\hline had completed morphogenesis & 0 & 100 & 100 & 0.0001 \\
\hline Percentage of endodormant terminal buds & 0 & 88 & 25 & 0.0001 \\
\hline
\end{tabular}

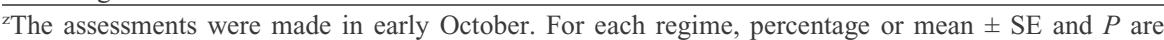
presented, $n=24$.

${ }^{y}$ Regime: MS, moderate moisture stress; SD, short days; SD+MS, short days with moderate moisture stress.

Table 2. Analysis of variance table for root dry weight of containerized coastal Douglas fir seedlings in early October.

\begin{tabular}{lrllll}
\hline Source & df & MS & Test & F & $P$ \\
\hline Regime & 2 & 0.1307 & $\mathrm{R} / \mathrm{R} \times \mathrm{B}$ & 4.1011 & 0.0754 \\
SD vs. SD+MS and MS & 1 & 0.2526 & $\mathrm{R} / \mathrm{R} \times \mathrm{B}$ & 7.923 & 0.0306 \\
Block in greenhouse & 3 & 0.0644 & $\mathrm{~B} / \mathrm{E}$ & 2.7492 & 0.0505 \\
Regime $\times$ block & 6 & 0.0319 & $\mathrm{R} \times \mathrm{B} / \mathrm{E}$ & 1.3599 & 0.2455 \\
Error & 60 & 0.0234 & & & \\
Total & 72 & 0.2510 & & & \\
\hline
\end{tabular}


Table 3. Performance attributes for containerized coastal Douglas fir seedlings given different dormancyinduction regimes. ${ }^{z}$

\begin{tabular}{lccrc}
\hline & \multicolumn{3}{c}{ Dormancy-induction regime $^{\mathrm{y}}$} & \\
\cline { 2 - 5 } Attribute & $\mathrm{MS}$ & $\mathrm{SD}$ & $\mathrm{SD}+\mathrm{MS}$ & $P$ \\
\hline Days to budbreak & $11 \pm 0.6$ & $5 \pm 0.3$ & $5 \pm 0.3$ & 0.0001 \\
Root growth capacity & $14 \pm 0.1$ & $16 \pm 2.3$ & $12 \pm 2.3$ & 0.5608 \\
\hline
\end{tabular}

${ }^{2}$ The assessments were made in late March after 15 days under ideal growing conditions. For each regime, mean $\pm \mathrm{SE}$ is presented, $n=20$.

${ }^{\mathrm{y}}$ Regime: MS, moderate moisture stress; SD, short days; SD+MS, short days with moderate moisture stress.

Table 4. Analysis of variance table for days to budbreak of containerized coastal Douglas fir seedlings in early March.

\begin{tabular}{lrrrrc}
\hline Source & df & \multicolumn{1}{c}{ MS } & Test & \multicolumn{1}{c}{ F } & $P$ \\
\hline Regime & 2 & 265.05 & $\mathrm{R} / \mathrm{R} \times \mathrm{B}$ & 38.6230 & 0.0001 \\
MS vs. SD and SD+MS & 1 & 529.00 & $\mathrm{R} / \mathrm{R} \times \mathrm{B}$ & 77.0856 & 0.0001 \\
Block in chamber & 4 & 3.38 & $\mathrm{~B} / \mathrm{E}$ & 1.0075 & 0.4137 \\
Regime $\times$ block & 8 & 6.86 & $\mathrm{R} \times \mathrm{B} / \mathrm{E}$ & 2.0485 & 0.0618 \\
Error & 45 & 3.35 & & & \\
Total & 60 & 278.64 & & & \\
\hline
\end{tabular}

Table 5. Survival and performance for containerized coastal Douglas fir seedlings given different dormancy-induction regimes. ${ }^{2}$

\begin{tabular}{lcccc}
\hline & \multicolumn{3}{c}{ Dormancy-induction regime $^{\mathrm{y}}$} & \\
\cline { 2 - 4 } Attribute & $\mathrm{MS}$ & $\mathrm{SD}$ & $\mathrm{SD}+\mathrm{MS}$ & \\
\hline Percentage of seedlings & 100 & 100 & 100 & \\
$\quad$ surviving & $6.6 \pm 0.2$ & $6.7 \pm 0.2$ & $7.0 \pm 0.2$ & 0.6514 \\
Root collar diam $(\mathrm{mm})$ & $8.40 \pm 0.42$ & $7.84 \pm 0.40$ & $7.90 \pm 0.52$ & 0.4412 \\
Shoot dry wt $(\mathrm{g})$ & $4.69 \pm 0.23$ & $4.68 \pm 0.24$ & $4.83 \pm 0.32$ & 0.6506 \\
Root dry wt $(\mathrm{g})$ & $8.0 \pm 0.4$ & $7.3 \pm 0.3$ & $7.7 \pm 0.4$ & 0.4686 \\
Leader length $(\mathrm{cm})$ & $159.4 \pm 6.5$ & $165.7 \pm 5.9$ & $163.4 \pm 7.0$ & 0.7171 \\
Number of needles on leader &
\end{tabular}

${ }^{2}$ The assessments were made in late October after one growing season in a common garden. Percentage or mean $\pm \mathrm{SE}$ is presented, $n=24$.

${ }^{y}$ Regime: MS, moderate moisture stress; SD, short days; SD+MS, short days with moderate moisture stress.

Indeed, all seedlings from the three regimes survived one growing season in a common garden (Table 5). As in the nursery assessment, root collar diameter and shoot dry weight of seedlings were not significantly different (Table 5). However, unlike the nursery assessment, there were no significant differences in root dry weight (Table 5). The length of the current-year leader was not affected by regime nor was the number of needles on it (Table 5), despite differences in timing of the completion of terminal bud morphogenesis in the nursery (Table 1).

In summary, seedlings from the three dormancy-induction regimes had similar morphology in the nursery with the exception of root dry weight. However, after one growing season in a common garden, differences in root dry weight were no longer apparent, and seedlings had similar survival and performance. With respect to coastal Douglas fir seedling morphological specifications that are used to cull seedlings at lifting (BCMOF, 2003), the three regimes did not prevent the seedlings from achieving the $3.0-\mathrm{cm}$ root collar diameter target specification nor did they result in seedlings that exceeded the $26-\mathrm{cm}$ maximum height specification. However, there were differences in the timing of onset of bud endodormancy and of budbreak after overwintering, and these are important considerations for seedlings destined for spring or autumn planting. For low-elevation spring planting, in which time for adequate root development before budbreak is important, seedlings given a MS regime are recommended. On mid- to highelevation sites that are autumn planted, seedlings given a SD regime are recommended because earlier bud endodormancy is an advantage. Finally, we urge nurseries producing autumn-planting stock to conduct trials to determine both the critical night length for their seed sources and the timing of the SD regime needed to ensure bud endodormancy for their earliest shipping dates.

\section{Literature Cited}

American Society for Horticultural Science (ASHS). 2002. ASHS Publications Style Manual. HortScience. Journal of the American Society for Horticultural Science ASHS Press, Alexandria, Va.

Arora, R., L.J. Rowland, and K. Tanino. 2003. Induction and release of bud dormancy in woody perennials: a science comes of age. HortScience 38:911-921.

Berlyn, G.P. and J.P. Miksche. 1976. Botanical microtechnique and cytochemistry. The Iowa Univ. Press, Ames, Iowa.

British Columbia Ministry of Forests (BCMOF). 2003. Seedling stock specifications for commercial forest nursery contracts. Govt. of
B.C., Victoria, B.C. 16 May 2006. http:// www.for.gov.bc.ca/nursery/HEADQTRS/ Specs2003.htm\#Seedling\%20Stock\%20Specification.

Burr, K.E. 1990. The target seedling concepts: bud dormancy and cold-hardiness, p. 79-90. In: R. Rose, S.J. Campbell, and T.D. Landis (eds.). The target seedling symposium. Proc. Combined Mtg. Western For. Nursery Assn. U.S. Dept. Agr., For. Serv., Gen. Tech. Rpt. RM-200.

Carlson, W.C. and C.L. Preisig. 1981. Effects of controlled-release fertilizers on the shoot and root development of Douglas-fir seedlings. Can. J. For. Res. 11:230-242

Carlson, W.C., W.D. Binder, C.D. Feenan, and C.L. Preisig. 1980. Changes in mitotic index during onset of dormancy in Douglas-fir seedlings. Can. J. For. Res. 10:371-378.

Grossnickle, S.C. 2000. Ecophysiology of northern spruce species: the performance of planted seedlings. NRC Research Press, Ottawa, Ont., Canada.

Grossnickle, S.C., J.T. Arnott, J.E. Major, and T.J. Tschaplinski. 1991a. Influence of dormancy induction treatments on western hemlock seedlings. I. Seedling development and stock quality assessment. Can. J. For. Res. 21:164 174.

Grossnickle, S.C., J.T. Arnott, and J.E. Major. 1991b. Influence of dormancy induction treatments on western hemlock seedlings. II. Physiological and morphological response during the first growing season on a reforestation site. Can. J. For. Res. 21:175-185.

Grossnickle, S.C. and R. Folk. 2005. Stock quality assessment of a somatic interior spruce seedlot. North. J. Appl. For. 22:197-202.

Hallé, F., R.A.A. Oldeman, and P.B. Tomlinson. 1978. Tropical trees and forests. An architectural analysis. Springer-Verlag, Berlin.

Handrek, K. and N. Black. 1989. Growing media for ornamental plants and turf. New South Wales University Press, Kensington, Australia.

Hermann, R.K. and D.P. Lavender. 1990. Pseudotsuga menziesii (Mirb.) Franco. Douglas-fir, p. 527-540. In: R.M. Burns and B.H. Honkala (eds.). Silvics of North America. Vol. 1. Conifers. U.S. Dept. Agr., For. Serv., Agr. Hdbk., 654, Washington, D.C.

Krasowski, M.J. and J.N. Owens. 1991. Growth and morphology of western red cedar seedlings as affected by photoperiod and moisture stress. Can. J. For. Res. 21:340-352.

Krasowski, M.J. and J.N. Owens. 1994. The use of mitotic index in seedling assessments. Can. J. For. Res. 24:2222-2234

Krasowski, M.J., J.N. Owens, and C.D.W. Hawkins. 1990. Effect of short day and drought treatments on development and early farm-field performance of western red cedar. Can.-B.C. Partnership Agreement on For. Resource Development: FRDA II. Joint publication of NRCan, Can. For. Serv.-Pacific For. Centre and BCMOF, Victoria, B.C. FRDA Rpt. 15539.

Lavender, D.P. 1991. Measuring phenology and dormancy, p. 403-422. In: J.P. Lassoie, and T.M. Hinckley (eds.). Techniques and approaches in forest tree ecophysiology. CRC Press, Boca Raton, Fla.

Matthews, R.G. 1982. Contrasting approaches to containerized seedling production. 1. British Columbia, p. 115-122. In: J.B. Scarratt, C. Glerum, and C.A. Plexman (eds.). Proc. Can. Containerized Tree Seedling Symp. Can.Ont. Joint For. Res. Committee Symp. Proc. O-P-10. 
O'Reilly, C., J.T. Arnott, and J.N. Owens. 1989a Effects of photoperiod and moisture availability on shoot growth, seedling morphology, and cuticle and epicuticular wax features on container-grown western hemlock seedlings. Can. J. For. Res. 19:122-131.

O’Reilly, C., J.N. Owens, and J.T. Arnott. 1989b. Bud development in container-grown western hemlock seedlings subjected to different dormancy induction treatments. For. Suppl. 62:169-179.

O'Reilly, C., J.N. Owens, J.T. Arnott, and B.G. Dunsworth. 1994a. Effect of nursery culture on morphological development of western hemlock seedlings during field establishment. I. Flushing, shoot elongation, and bud development. Can. J. For. Res. 24:53-60.
O'Reilly, C., J.N. Owens, J.T. Arnott, and B.G. Dunsworth. 1994b. Effect of nursery culture on morphological development of western hemlock seedlings during field establishment. II. Survival, shoot length components, and needle length. Can. J. For. Res. 24: 61-70.

Owens, J.N. and M. Molder. 1973. A study of DNA and mitotic activity in the vegetative apex of Douglas-fir during the annual growth cycle. Can. J. Bot. 51:1395-1409.

Ritchie, G.A. 1984. Assessing seedling quality, p. 243-259. In: M.L. Duryea, and T.D. Landis (eds.). Forest nursery manual: production of bareroot seedlings. Martinus Nijhoff/Dr W. Junk Publishers, The Hague, Netherlands.
Ritchie, G.A. and T.M. Hinckley. 1975. The pressure chamber as an instrument for ecological research. Adv. Ecol. Res. 9:165-254.

Simpson, D.G. and G.A. Ritchie. 1997. Does RGP predict field performance? A debate. New For 13:253-277.

SoftwareInc, SYSTAT Software, Inc.. 2004. SYSTAT 11. Statistics II. SYSTAT Software, Inc., Richmond, Calif.

van Eerden, E. and J.W. Gates. 1990. Seedling production and processing: container, p. 226234. In: D.P. Lavender, R. Parish, C.M. Johnson, G. Montgomery, A. Vyse, R.A. Willis, and D. Winston (eds.). Regenerating British Columbia's forests. Univ. of British Columbia Press, Vancouver, B.C. 